BIOKEMISTRI 16(2):80-87 (December 2004)

Printed in Nigeria
An international journal published by the

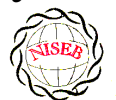

OVigerian \&ociety for \&̊xperimental Biology

\title{
Assessment of protein quality of processed melon seed as a component of poultry feed
}

\author{
Oyelola B. OLOYEDE ${ }^{1}$, Gloria A. OTUNOLA ${ }^{2}$ and Daniel F. APATA ${ }^{3}$
}

1. Department of Biochemistry, University of Ilorin, Ilorin, Nigeria

2. Department of Chemistry, IBAS, Kwara State Polytechnic, Ilorin, Nigeria

3. Department of Animal Production, University of Ilorin, Nigeria

Received 17 November 2003

MS/No BKM/2003/050, @ 2004 Nigerian Society for Experimental Biology. All rights reserved.

\begin{abstract}
Ninety six day - old broiler chicks were used in a 4 - week feeding trial to determine the protein quality of processed melon seed as a component of broiler chick diet. The protein quality was assessed using blood associated parameters including Haemoglobin indices and selected serum enzymes. The processed melon seed meals were Raw Melon Seed Meal (RMM), Fermented Melon Seed Meal (FMM) and Fermented Cooked Melon Seed Meal (FCMM). The three test ingredients (RMM, FMM and FCMM) were included as the sole source of protein in a basal broiler chick starter diet. The soybean seed meal (SBM) based commercial broiler chick starter diet served as the control. Blood associated parameters like Haemoglobin (Hb), PCV, RBC, WBC, Total Protein, Creatinine, Uric acid, GPT, GOT and ALP were used to assess the protein quality of the diets fed. There were four (4) experimental groups, each made up of eight birds in three replicates, allocated to the experimental diets (SBM (Control), RMM, FMM and FCMM) respectively. Of all the groups of broiler chicks, those placed on the FCMM diet gave blood associated parameters that were similar in value to those of the broiler chicks placed on the control (SBM) diet; while values obtained for broiler chicks placed on the other diets RMM and FMM were quite low. The results indicated that the processing of melon seeds by cooking and fermentation made the protein in melon seed more available to the broiler chicks, and also removed some or all of the antinutritional factors in raw melon seed. It is therefore concluded that the simultaneous processing of melon seed using cooking and fermentation techniques before its inclusion in broiler chick starter diets, enhances the protein quality and status of melon seed as a component of broiler starter diet.
\end{abstract}

Key words: Protein quality, melon seed, cheeks, haematological indices

${ }^{1}$ Author to whom correspondence should be addressed.

E-mail: adeglo2004@yahoo.com Tel: 08033736994 


\section{INTRODUCTION}

The major hindrance to commercial poultry production in Nigeria is the unavailability and high cost of feed which arises from the competition between man and animals for the available grains. Feed elements especially proteins constitute a high component in poultry production cost, as much as $75 \%$ for broilers and $65 \%$ for layers ${ }^{1}$. Legumes are very important sources of protein and lipid in animal nutrition though their use is limited by the presence of antinutritional factors. ${ }^{2}$ Soybean has been used as a sole supplementary protein source in poultry feed for a long time. Of recent, however, soybean is being implicated in diet as a possible inducer of goiter in infants ${ }^{3}$, attributable to the presence of compounds that inhibit thyroid peroxidase (ITPO) catalysed reactions essential to thyroid hermone synthesis. ${ }^{3}$

In view of the competition between man and animals for the available conventional legumes like soybean and groundnut, efforts are being channeled towards the use of nonconventional feed stuff especially, legumes, available locally for livestock feed. It is expected that these alternatives should have comparative nutritive values to the conventional ones, be easy to cultivate, as well as, be cheap. ${ }^{4}$

Melon (Citrullus vulgaris), is a protein oil - rich seed. It is a cheap and readily available legume which may reduce feed cost and make poultry production more profitable. ${ }^{4}$ Melon seeds are produced mostly in Southern Nigeria where poultry production is mostly concentrated. ${ }^{5}$ Unextracted 'full fat' melon seeds are rich sources of energy, (oil content of 51 to $55 \%$ ) and crude protein (32.5 to $38.7 \%)^{6}$. These give melon seeds the potential of supplying both energy and protein in poultry diets, and may reduce feed cost. When melon is used as the main source of protein in a balanced ration, it is readily digestible, and its biological value and efficiency of its utilization were observed to be inferior only to those of animal protein, although melon seed is low in lysine an essential amino $\operatorname{acid}^{6}$. Melon seeds have been reported to be as good as soybean in all the essential amino acids except lysine ${ }^{7}$. Broiler chicks fed raw melon seeds have been reported to show feed refusal within 24 hours, severe weight loss after five days and mortality by the seventh day, an indication of the presence of antinutrients, while toasting of the melon seed gave normal growth and no mortality. ${ }^{8}$ Broiler birds fed on raw melon seeds have also been reported to have lower feed intake and body weight gain when compared to those fed on toasted melon seed meal, though toasting seems to have no noticeable effect on the nutrient availability and digestibility of the birds. ${ }^{9}$

Antinutrients present in melon seeds are trypsin and chymotrypsin inhibitors which can be removed by heat treatments. ${ }^{10}$ Processing techniques like toasting, autoclaving, pelleting, solvent extraction, defatting, cooking and fermentation are effective ways of achieving desirable changes, removal of undesirable components and effective utilization of the full potential of legumes as feed stuff.

The present study therefore investigates some selected associated blood parameters of broiler chicks fed on raw and processed (defatted, fermented and cooked) melon seed based diets.

\section{MATERIALS AND METHODS}

Day old broilers (96) weighing an average of $35.05 \pm 2.15 \mathrm{~g}$ each were purchased at a poultry farm, Evergreen farms, located at Gaa - Imam, Ilorin, Nigeria.

The melon seeds used were purchased at the local market in Idi - Ape in Ilorin, Nigeria. The other feed ingredients, - maize, maizebran, premix etc. were purchased from D.J. Ventures, Nigeria Ltd. Asa Dam Road, Ilorin.

\section{Processing of the Melon Seeds}

Defatting: The dry melon seeds were winnowed using trays, handpicked to remove grits and dirts, after which they were milled using the common engine grinder. The milled powder was kneaded with water for thirty minutes until oil from the melon seeds started to flow. Since this method is not sufficient to remove a considerable amount of the oil, the kneaded melon dough was then put in a jute bag and the oil extracted under pressure by placing heavy stones on it for twelve (12) hours. 


\section{Fermentation}

The defatted melon cake was put in a jute bag, which was further wrapped in black polythene bags and kept in a plastic drum with a good cover to provide warmth for seven days. Fermentation was established by an increase in acidity. ${ }^{11}$

\section{Cooking and Fermentation}

After defatting, the melon cake was cooked in boiling water for 30 minutes before subjection to fermentation as described above.

\section{Drying}

The melon cakes were oven - dried at $60^{\circ} \mathrm{C}$ and then milled prior to their inclusion as components of the various diets.

\section{Birds and Their Management}

The metabolic cage used was washed and thoroughly disinfected with morigard disinfectant two weeks before the arrival of the chicks. The surrounding environment and all equipment used were thoroughly cleaned and disinfected. The cage was electrically heated for twenty four (24) hours before the arrival of the birds. The day-old broiler chicks were acclimatized for 5 days, and were randomly allocated to four (4) experimental starter diets after weighing. Each diet was replicated three times with eight (8) birds in each treatment. The control diet was the commercial soybean meal based diet.

Proximate and percentage compositions of the melon seed meals and the experimental diets are shown in Tables 1, 2 and 3 respectively. Feed and tap water were administered ad libitum, and the birds were vaccinated against Coccidiosis, Gumboro and New Castle diseases at one, two and three weeks respectively. The growth parameters are as given in a previous study. ${ }^{12}$

\section{Haematological Analysis}

At the end of 28 days (4 weeks), blood was sampled from three birds per treatment by sacrificing the birds. Samples for haematological analysis were collected after severing the jugular of the birds, in EDTA treated sample bottles to prevent coagulation; while those for serum analysis were collected without the anticoagulant. Packed Cell Volume (PCV), Red Blood Cell (RBC), White Blood Cell (WBC), and Haemoglobin $(\mathrm{Hb})$ were determined using the Wintrobes Microhaematocrit centrifuge, Neubaer haematocytometer and Sahli's methods respectively. The differential white blood cell counts were obtained by making a differential count with Wright's Stain ${ }^{13}$.Serum creatinine was determined using the alkaline picrate method, ${ }^{14}$ while serum uric acid was determined by the method of caraway. Glutamate Pyrivate Transaminase (GPT), Glutamate Oxaloacetate Transaminase (GOT) and Alkaline Phosphatase (ALP) activities were determined by the methods of ${ }^{15,16,17,18}$. Total protein content was determined by the Biuret method. ${ }^{17}$

\section{Statistical Analysis}

All data were subjected to analysis of variance $(A N O V A)^{18}$ and the significant difference between the treatment and the control were determined using the Duncan's Multiple Range Test. ${ }^{19}$

\section{RESULTS AND DISCUSSION}

Haematological parameters are used in the assessment of proteins quality and utilization. Alterations in the qualitative and quantitative composition as well as the biochemistry of the blood cells, are warning signals on, and is indicative of an impaired function. $^{20}$

Table 4 shows the haematological profile of broiler birds fed on the various experimental diets. Haemoglobin status was observed to be $35.67 \pm 0.94,27.33 \pm 1.89$, $31.00 \pm 3.55$ and $33.33 \pm 0.94$ for broiler birds fed on the control (SBM) diet, RMM, FMM and FCMM diets respectively. When compared to the control, the $\mathrm{Hb}$ values obtained for the experimental diets were significantly low. The same trend was observed for PCV, RBC and WBC status, with birds fed on the control diet having significantly higher values than those fed on the experimental diets. However, broiler birds fed on the fermented cooked melon meal diet had values that are relatively similar to those of the broilers fed on the control diet.

The generally low $\mathrm{Hb}, \mathrm{PCV}$ and $\mathrm{RBC}$ value of broiler birds fed on the RMM and FMM 
Table 1: Composition of Experimental Diets/100g

\begin{tabular}{|c|c|c|c|c|}
\hline Ingredients & SBM (Control) & RMM & FMM & FCMM \\
\hline Maize & 46.00 & 46.00 & 46.00 & 46.00 \\
Melon Cake & 36.00 & 36.00 & 36.00 & 36.00 \\
Maize Bran & 6.00 & 6.00 & 6.00 & 6.00 \\
brewers Dry Grain & 8.00 & 8.00 & 8.00 & 8.00 \\
Bone Meal & 2.54 & 2.54 & 2.54 & 2.54 \\
Oyster Shell & 1.00 & 1.00 & 1.00 & 1.00 \\
Salt & 0.20 & 0.20 & 0.20 & 0.20 \\
Vit/Mineral Premix & 0.25 & 0.25 & 0.25 & 0.25 \\
*Lysine & - & 0.01 & 0.01 & 0.01 \\
+Methionine & 0.01 & - & - & - \\
\hline
\end{tabular}

*Lysine was added to the melon meal diets because it is a limiting amino acid in melon seeds.

+ Methionine was added to the soyabean meal diet because it is a limiting amino acid in soybean.

Table 2: Proximate Composition of RMC, FMC AND FCMC.

\begin{tabular}{|l|c|c|c|}
\hline \multicolumn{1}{|c|}{ Constituent (\%) } & RMM & FMM & FCMM $^{\mathrm{C}}$ \\
\hline Crude Protein & $43.86 \pm 0.09$ & $46.38 \pm 0.01$ & $46.81 \pm 0.01$ \\
\hline Ether Extract & $21.05 \pm 0.02$ & $17.40 \pm 0.08$ & $15.00 \pm 0.04$ \\
\hline Crude Fibre & $7.00 \pm 0.00$ & $5.45 \pm 0.08$ & $5.25 \pm 0.08$ \\
\hline Ash & $4.00 \pm 0.00$ & $5.25 \pm 0.03$ & $5.75 \pm 0.08$ \\
\hline Carbohydrate & $22.20 \pm 0.03$ & $20.57 \pm 0.06$ & $18.28 \pm 0.07$ \\
\hline
\end{tabular}

Determination was on dry matter basis. Each value is a mean of triplicate determinations.

A: Raw Melon Meal - Control; B: Fermented Melon Meal; C:Fermented Cooked Melon Meal

Table 3: Proximate Composition of Experimental Diets (g)

\begin{tabular}{|c|c|c|c|c|c|}
\hline Diet & Crude Protein & Crude Fibre & Ether Extract & Ash & Carbohydrate \\
\hline $\begin{array}{c}\text { SBM }^{\mathrm{A}} \\
\text { Control }\end{array}$ & $35.25 \pm 0.08$ & $6.00 \pm 0.00$ & $8.00 \pm 0.00$ & $7.5 \pm 0.62$ & $33.25 \pm 0.08$ \\
\hline RMM $^{\mathrm{B}}$ & $28.28 \pm 0.01$ & $5.50 \pm 0.04$ & $12.50 \pm 0.06$ & $7.00 \pm 0.12$ & $37.22 \pm 0.06$ \\
\hline FMM $^{\mathrm{C}}$ & $30.65 \pm 0.08$ & $6.00 \pm 0.00$ & $10.00 \pm 0.00$ & $6.00 \pm 0.12$ & $39.35 \pm 0.08$ \\
\hline FCMM $^{\mathrm{D}}$ & $35.34 \pm 0.02$ & $6.00 \pm 0.00$ & $8.00 \pm 0.00$ & $9.50 \pm 0.04$ & $31.16 \pm 0.06$ \\
\hline
\end{tabular}

Determination was on dry matter basis. Each value is a mean of triplicate determination \pm standard deviation.

A: Soybean Meal; B: Raw Melon Meal; C: Fermented Melon Meal; D: Fermented Cooked Melon Meal. 
diets might be indicative of the presence of antinutritional factors in the diets. ${ }^{21}$ The effect of the processing techniques of cooking and fermentation on antinutritional factors is reflected on the values of the blood parameters of broilers fed on the FCMM based diet, as they were relatively the same as that of broilers fed on the control (SBM) diet, and both of them (the control and the FCMM) were significantly different from those of birds fed on RMM and FMM diets. A similar trend has been reported for rats and rabbits fed on some raw and/or processed tropical legumes ${ }^{21}$, pueraria seeds ${ }^{22}$ and thevetica cake ${ }^{23}$ based diets respectively.

Table 4: Haematological Indices of Broiler Chicks Fed on Soybean Melon Meal Based Diets Over a Period of 28 days.

\begin{tabular}{|c|c|c|c|c|}
\hline Diets & Hb\% & PCV \% & RBC (x10 $12 / 1)$ & WBC (x10 $/ 1)$ \\
\hline SBM Control & $35.67 \pm 0.94^{\mathrm{a}}$ & $29.33 \pm 0.47^{\mathrm{a}}$ & $279.33 \pm 5.44^{\mathrm{a}}$ & $10.40 \pm 0.36^{\mathrm{b}}$ \\
RMM & $27.33 \pm 1.89^{\mathrm{b}}$ & $22.33 \pm 0.47^{\mathrm{b}}$ & $206.00 \pm 30.47^{\mathrm{b}}$ & $12.10 \pm 0.65^{\mathrm{a}}$ \\
FMM & $31.00 \pm 3.56^{\mathrm{b}}$ & $24.33 \pm 12.35^{\mathrm{b}}$ & $228.33 \pm 21.54^{\mathrm{b}}$ & $11.93 \pm 0.05^{\mathrm{a}}$ \\
FCMM & $33.33 \pm 0.94^{\mathrm{a}}$ & $27.00 \pm 10.00^{\mathrm{a}}$ & $256.67 \pm 8.18^{\mathrm{a}}$ & $10.64 \pm 0.544^{\mathrm{b}}$ \\
\hline
\end{tabular}

SBM (Control): Soybean Meal; RMM: Raw Melon Meal; FMM: Fermented Melon Meal; FCMM: Fermented Cooked Melon Meal. Results are mean of 3 determinations $\pm S D$. Values along the same column carrying the same superscripts are not significantly different.

Table 5: Serum Total Protein, Uric Acid and Creatnine of Birds Fed on the Experimental Diets Over a Period of 28 Days.

\begin{tabular}{|c|c|c|c|}
\hline Diets & Total Protein $(\mathrm{g} / \mathrm{l})$ & Uric Acid $(\mathrm{nmol} / \mathrm{l})$ & Creatmine $(\mathrm{nmol} / \mathrm{l})$ \\
\hline SBM Control & $25.67 \pm 0.03^{\mathrm{b}}$ & $0.46 \pm 0.08^{\mathrm{b}}$ & $55.60 \pm 7.04^{\mathrm{b}}$ \\
RMM & $22.67 \pm 0.03^{\mathrm{a}}$ & $11.93 \pm 0.44^{\mathrm{a}}$ & $53.60 \pm 4.71^{\mathrm{a}}$ \\
FMM & $22.67 \pm 0.03^{\mathrm{a}}$ & $1.17 \pm 0.21^{\mathrm{a}}$ & $50.33 \pm 8.58^{\mathrm{b}}$ \\
FCMM & $25.00 \pm 0.02^{\mathrm{b}}$ & $0.93 \pm 0.16^{\mathrm{b}}$ & $55.00 \pm 10.42^{\mathrm{b}}$ \\
\hline
\end{tabular}

Table 6: Serum GPT, GOT and ALP Activities of Birds Fed On the Experimental Diets Over a Period of 28 Days.

\begin{tabular}{|c|c|c|c|}
\hline Diets & $\begin{array}{c}\text { GPT } \\
(\mathrm{nmol} / \mathrm{mg} / \mathrm{prot})\end{array}$ & GOT $(\mathrm{nmol} / \mathrm{mg} /$ prot $)$ & ALP (nmol/mg/prot). \\
\hline SBM (Control) & $19.33 \pm 4.49^{\mathrm{b}}$ & $89.00 \pm 0.00^{\mathrm{b}}$ & $239.33 \pm 5.25^{\mathrm{a}}$ \\
RMM & $24.33 \pm 4.64^{\mathrm{a}}$ & $98.67 \pm 0.30^{\mathrm{a}}$ & $249.33 \pm 6.18^{\mathrm{b}}$ \\
FMM & $17.00 \pm 0.82^{\mathrm{a}}$ & $81.33 \pm 0.17^{\mathrm{b}}$ & $247.33 \pm 7.41^{\mathrm{b}}$ \\
FCMM & $20.33 \pm 0.42^{\mathrm{b}}$ & $89.00 \pm \mathrm{s} 0.00^{\mathrm{b}}$ & $232.67 \pm 1.25^{\mathrm{a}}$ \\
\hline
\end{tabular}

Results are means of 3 determinations $\pm S D$. Values along the same column carrying the same superscripts, are not significantly different $(P<0.05)$. 
Effect of the experimental diets on the serum total protein, uric acid and creatnine are shown in Table 5. Broiler birds fed on the control (SBM) and FCMM diets had total protein values of $25.67 \pm 0.03$ and $25.00 \pm 0.02$ respectively, while broilers on the RMM and FMM diets had values of $22.00 \pm 0.47$ and $22.67 \pm 0.02$ respectively. Serum total protein consists of albumin and globulus changes in the nutritional status of an animal are easily detected in the albumin, which is about two - thirds of total protein. Information regarding nutritional status and malnutrition is often obtained from the total protein. ${ }^{24}$ The values for all the experimental diets, although slightly different were within the normal values for broiler chicks. $^{25}$

Uric acid values was $0.46 \pm 0.08$ and $0.93 \pm 0.16$ for broilers fed on the control $(\mathrm{SBM})$ and FCMM diets respectively; $1.93 \pm 0.49$ and $1.17 \pm 0.21$ respectively for RMM and FMM. Uric acid gives an indication of the quality of protein fed and high levels in the serum occur when energy deficiency and/or diseases prevent the efficient utilization of protein. In the present study, broiler birds fed on the RMM and FMM diets had higher uric acid values than those fed on the control and FCMM diets, an indication of inefficient utilization of the protein in these diets. $^{26}$ This could be as a result of antinutrients that were not completely removed which was also corroborated by the low serum total protein observed in these groups of birds.

Broiler birds fed on RMC and FMC based diets had slightly low values of creatnine, $53.60 \pm 4.71$ and $50.33 \pm 8.58$ respectively compared to those of the control (SBM) and FCMM based diets 55.6 \pm 7.04 and $55.00 \pm 10.42$ respectively. This could be attributed to improper nutrient utilization, since serum values of these parameters depend on the quality and quantity of protein in the diet.

Table 6 shows the activities of the serum enzymes Glutamate Pyruvate Transaminase (GPT), Glutamate - Oxaloacetate Transaminase (GOT) and Alkaline Phosphatase (ALP). The amino transferases are the most common indicators of cellular malfunction, they are found in small quantities in the serum, with higher values indicating a disease or malfunction in the liver. $^{25}$
In the present study, the GPT value ranged from $19.33 \pm 4.50, \quad 24.33 \pm 4.64$, $17.00 \pm 0.82$, to $20.33 \pm 0.42$ in broilers fed on the SBM, RMM, FMM and FCMM respectively. Although the values were different for all the experimental diets, they were all within the normal range value for serum GPT in chicken which ranges from $1-37$ I.U// ${ }^{27}$. For GOT, the values ranged from $89.00 \pm 0.00,98.67 \pm 0.30$, $81.33 \pm 0.17$ to $89.00 \pm 0.00$ for broilers fed on the control (SBM), RMM, FMM and FCMM respectively. The RMM had the highest enzyme activity. This could be as a result of the negative effect of antinutrients present in the raw melon meal. These antinutrients could have been destroyed by cooking and fermentation as demonstrated by birds fed on the FCMC diet which compared favourably to those fed on the control diet. This agrees with the report that some antinutrients like phytohaemaghitinin activity are reduced with cooking. ${ }^{11}$

ALP activity was highest in broilers fed on the RMM diet (249.33 \pm 6.18$)$, followed by those fed on the FMM diet $(247.33 \pm 7.40)$ statistically similar values, $232.67 \pm 1.25$ and $239.33 \pm 5.50$ were obtained for broilers fed on the FCMM and control (SBM) diets respectively. ALP is used to detect pathology of the live and bone. High levels in the serum therefore is an indication of pathology. This could be attributed to the presence of antinutrients in the raw melon based diet which led to poor absorption and utilization of the diet.

\section{CONCLUSION}

The present study investigates the protein quality of processed and unprocessed melon seed based diets on some haematological parameters in the broiler chicks. From the result obtained, it can be seen that processing melon seed meal by cooking and fermenting before its inclusion into broiler diets makes the protein in the diet more available and well utilized by the broilers as demonstrated by the broilers fed on the FCMM diet which shows values closest to the control broilers. The birds fed on the unprocessed melon meal diet (RMM), showed the worst haematological parameters as there were wide, negative and statistically different 
values to the control because it did not undergo any processing.

The FMM diet was better than the RMM because it underwent the process of fermentation. It is therefore concluded that some antinutrients are present in melon seeds which cannot be totally removed by defatting or fermentation alone and that in the raw state, the protein is unavailable, but the combination of cooking and fermentation of melon seed before its inclusive in broiler chicks starter diets, enhances the nutritional status of melon meal as a protein component of broiler diets.

\section{REFERENCES}

1. Atteh, J. O. Ibiyemi, S. A. and Ojo, A.O. (1995) Responses of Broilers to Dietary Levels of Thevetia Cake. J. Agric. Sci. 125: $307-310$.

2. Nwokolo, E. and Sim, J.S. (1987) Nutritional Assessment of Defatted Meals of Melon (Colocyntis Citrullus) and Fluted Pumpkin (Telfaria Occidetals Hook) by Chick Assay. J. Food Sci. Agric. 38: 237 246.

3. Divi, R.L., Chang, H.C. and Doerge, D.G.R. (1997) Antithyroid Isoflavones from Soybean: Isolation Characteristization and Mechanism of Reaction. Biochem. Pharmaco. 54910: 1087 - 1096.

4. Nwokolo, E. (1986) Growth and Organ Weights of Chicks Fed on Processed Pigeon Pea Meal Supplemented With Lysine and Methionine. Nig. J. Nutr. Sci. 7: 78 - 80.

5. Oji, U.I., Oruwari, B.M. and Iwuagila, R.O. (1999) Performance of Growing Broiler Chicken Fed Toasted and Untoasted Melon (Colocynthis Citrullus) Seed Meal. Trop. J. Anim. Sci. 1: 43 - 49.

6. Oyenuga, V.A. (1978) Nigerian Foods and Feeding Stuffs. Their Chemistry and Nutritive Values. Ibadan University Press. Ibadan. Pp. 8 - 16; 8689.
7. Nwokolo, E.N. and Sim, J.S. (1987) Nutritional Assessment of Defatted Meals of Melon and Fluted Pumpkin by Chick Assay. J. Sci. Food. Agric. 38: 237 - 246.

8. Oruwari, B.M., Oji, U.I. and Iwuagita, R.O. (1999) Biovalable Energy Value and Digestibility of Whole Melon Seed Meal (Colycynthis Citrullus) in Broiler Chicken. Trop. J. Anim. Sci. 2: 52 - 59.

9. Fernandez, M.G., Carmen - Monreau, U.L., Frais, M., Diazpollan, M.F. and Violalverde, C. (1995) Nutritional Lentis Oil Meal in Simplified Chick Ration. Poult. Sci. 27: 621 - 626.

10. Osagie, A.U. (1998) Antitnutritional Factors In: Nutritional Quality of Plant Foods (Osagie, A.U. and Eka, O.U. eds). Published by the Post Harvest Research Unit Dept. of Biochemistry Uniben, Benin City, Nigeria.

11. Otunola, G.A., Oloyede, O.B., and Apata, D.F. (2002) Effects of Replacing Soybean Meal with Raw or Fermented Melon Cake on the Performance of Broiler Chicks. Bioscience Research Communications 14:115 - 122.

12. Achinewhu, S.C. (1986) Effects of Fermentation on Carbohydrates and Fatty Acid Composition of African Oil Bean Seed (Pentachlethra macrophyella) Food Chem. 19: 105 - 116.

13. Wright, P. J., Leathwood, P. D. and Plummer, D.T. (1972) Enzymes in Rats: Alkaline Phosphatase. Enzymologia 42: $317-327$.

14. Scott, C. (1965) Plasma Creatinine Determination; a new and specific reaction method. Scand. J. Lab. Invest. 17: 381.

15. Reiteman, S. and Frankel, S. (1957) A Colorimetric Method for the Determination of Serum GOT and GPT. Am. J. Clin. Pathol. 28: 56 - 63. 
16. Schmidt, E., and Schmidt, F.W. (1963) Enzymes. Clin. Biol. 3: 1 - 8.

17. Bassey, O.A., Lowry, O.H. and Brock, M.D. (1946) A Method for the Rapid Determination of Alkaline Phosphatase with Cubic Millimeters of Serum. J. Biol. Chem. 164: 321 - 392.

18. Steel, R.G.O. and Torrie, J.H. (1960) Principles and Procedures of Statistics. McGraw Hill Book Company Inc. London.

19. Duncan, D.B. (1955) Multiple Range and Multiple F - Tests. Biometrics 11:1.

20. Stroev, E.A. (1989) Biochemistry. Mir Publishers. Pp. 9 - 55.

21. Apata, D. F. (1990) Biochemical and Nutritional Toxicological Assessment of Some Tropical Legume Seeds. A Ph.D. Thesis Submitted to the Department of Nutritional Biochemistry, Animal Science, Faculty of Agriculture, University of Ibadan, Nigeria.
22. Awosanya, J.K., Apata, D.F. and Ayoola, M.A. (1990) Blood Chemistry and Carcass Yield of Cockerels Fed on Melon Husk Diet. Trop. J. Anim. Sci. 2: 89 - 96.

23. Atteh, J.O., Ibiyemi, S.A. and Ojo, A.O. (1995) Response of Broilers to Dietary Levels of Thevetia Cake. J. Agric. Sci. 125: $307-310$.

24. Allison, J.B.Z. (1995) Biological Evaluation of Proteins. Physical Rev. 35: $664-669$.

25. Rosenthal, P. (1977) Assessing Liver Function and Hyperbilinemia in the New Born. Clin. Chem. 43: 228 - 234.

26. Akinola, S.O. and Abiola, S.S. (1990) Blood Chemistry and Carcass Yield of Cockerels. Fed on Melon Husk Diet. Trop. J. Anim. Sci. 2:39 - 44.

27. Ker, G.R., Lae, E.S., Lan, M.K.M, Lamor, R.J., Randell, E. and Forhoter, R. (1982) Relationship Between Diet and Biochemical Measures of Nutritional Status. Am. J. Clin. Nutr. 35: 294 - 308. 